\title{
Child Sexual Abuse, Links to Later Sexual Exploitation/High-Risk Sexual Behavior, and Prevention/Treatment Programs
}

\author{
Kevin Lalor \\ Technological University Dublin, kevin.lalor@tudublin.ie \\ Rosaleen McElvaney \\ Technological University Dublin, rosaleen.mcelvaney@tudublin.ie
}

Follow this and additional works at: https://arrow.tudublin.ie/aaschsslarts

Part of the Child Psychology Commons

\section{Recommended Citation}

Lalor, K. \& McElvaney, R. (2010). Child sexual abuse, links to later sexual exploitation/high risk sexual behavior and prevention/treatment programmes. Trauma, Violence and Abuse, (11), 159-177.

doi:10.1177/1524838010378299

This Article is brought to you for free and open access by the Social Sciences at ARROW@TU Dublin. It has been accepted for inclusion in Articles by an authorized administrator of ARROW@TU Dublin. For more information, please contact arrow.admin@tudublin.ie, aisling.coyne@tudublin.ie,gerard.connolly@tudublin.ie. Funder: ISPCAN

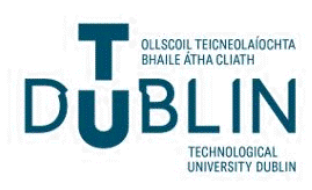


Unfortunately, evidence worldwide indicates that children and adolescents are at risk from sexual predators, exploiters and opportunists. Incidence varies from time to time and from place to place, depending on individual, familial and societal circumstances, but the sexual exploitation of young people appears to be a universal phenomenon. The extant research also shows that family members, relatives, neighbours or those known and trusted by the child, typically perpetrate abuse.

Scientific literature on the nature and incidence of child sexual abuse (CSA) has existed for almost 150 years. Masson (1992) details the recognition of CSA by physicians in $19^{\text {th }}$ century France. For example, he describes Tardieu's A Medico-Legal Study of Assaults on Decency, which noted that 9,125 people were accused of rape or attempted rape of children between 1858 and 1869.

In more recent times, widespread recognition of child abuse is typically dated to the US in the early 1960s. Initial concerns were with the "battered child syndrome." This term was first used by paediatrician C. Henry Kempe at a 1961 symposium of the American Paediatric Society (Kempe, Silverman, Steele, Droegmueller \& Silver, 1962). The identification of this syndrome came about through observations of the large numbers of unexplained broken bones and bruises in children on paediatric wards. The growing awareness and concern regarding, first, child physical abuse and, later, child sexual abuse in the medical and child protection literature in the US in the 1960s and 1970s has been well documented elsewhere (Schultz, 1982; DeMause, 1991).

The purpose of this article is to review the literature on the nature and incidence of CSA internationally, with a particular focus on perpetrators; to explore the link between CSA and (later) exploitation outside the family; to review the literature on CSA prevention strategies; and to review the literature on effective interventions and best practices in CSA services.

\section{Overview of the Nature and Incidence of Child Sexual Abuse}

In an early international perspective on child abuse, the Foreword to Korbin's Child abuse and neglect: Cross-cultural perspectives (1981) states "child abuse ... has become a serious social problem in the United States and in some other industrialized countries, yet it occurs infrequently or not at all in many of the world's societies" (p. vii). We now know that this is not the case.

In an important study, Finkelhor (1994) aimed to illustrate the international epidemiology of CSA and found that research studies in 19 countries produced findings similar to North American research (incidence rates ranging from 7 to 36 per cent for women and 3 to 29 per cent for men), thus undermining the idea that CSA is "peculiarly American". He concluded:

Studies from a variety of countries suggest that sexual abuse [of children] is indeed an international problem. In every locale where it has been sought, researchers have demonstrated its existence at levels high enough to be detected 
through surveys of a few hundred adults in the general population ... As such epidemiological findings are available for more and more countries, the responsibility of proof shifts to anyone who would argue that sexual abuse is rare or nonexistent in their locale (1994, p. 412).

Finkelhor (1994) noted the preponderance of results from Caucasian, Western, Christian countries and the relative lack of data from middle-Eastern, African or Far-Eastern countries. Lachman (1996), also noted the absence of research on child abuse in Africa ${ }^{1}$ where it is "overshadowed by political and economic problems, lack of resources, the enormity of the phenomenon, and the lack of a research culture and research experience" (1996, p. 543). However, he did note a growing number of publications from Africa in international journals.

Today, although many gaps remain, we have better information about the nature and incidence of CSA throughout the world. In the material below, selected studies are summarised. Data on incidence and perpetrators, in particular, are highlighted. Firstly, however, it is important to highlight some methodological considerations.

\section{Child Sexual Abuse Research: Definitions and Methodological Considerations}

The methodological limitations of child abuse research have long been recognised (Briere, 1992; Runyan, 2000; Widom, 1988). In addition to the inherent secrecy and sensitivity of the issue, numerous methodological issues must be noted.

First, researchers use a wide variety of definitions of 'childhood sexual abuse'. Many general population surveys define it as 'unwanted sexual contact' without asking for specific details of the behaviour. Some studies distinguish between 'contact abuse' and 'non-contact abuse' or 'penetrative abuse' and 'non-penetrative abuse'. Studies use different age cut off points (before the age of 15,16, 17 or 18) to define CSA. Studies that focus on more broadly based definitions of CSA not surprisingly indicate higher prevalence rates.

Second, studies have been conducted amongst a range of different samples; college samples, convenience samples, clinical samples, national probability samples. The latter are the least commonly studied, given the cost involved, but yield the most generalisable data.

\footnotetext{
${ }^{1}$ The phenomenon of 'transactional sex' must be considered in the African context. Sexual relations between younger female adolescents and older boys or men, with the exchange of small gifts or money, are frequently exploitative. García-Moreno and Watts (2000) refer to this as "economically coerced sex" (p. 261). Older boys/men who provide financial/economic support to young girls are widely known as "sugar daddies.' Whilst most likely to occur in conditions of poverty and deprivation, such relationships have also been noted amongst the middle and privileged classes, where additional funds may be used for fashionable clothes, mobile phones and other luxury items. Silberschmidt (2001) argues that the patterns of sexual behaviour evident in parts of sub-Saharan Africa today are not the result of some traditional "permissiveness", but the result of the breakdown of traditional norms and regulations surrounding sexual behaviour, aggravated by widespread poverty and social upheaval.
} 
Third, and perhaps most importantly, prevalence rates are accurate only to the extent that respondents are willing to discuss the topic with researchers or complete questionnaires. Consider the response rates reported in the following studies: McGee, Garavan, de Barra, Byrne and Conroy (2002); Ireland, national sample of adults - 71\%; Chen, Dunne and Han (2004); (China, sample of high school students - 70.5\%; Briere and Elliott (2003);US, national sample of adults - 64.8\%; Steel and Herlitz (2005);Sweden, national sample of adults $-59 \%$.

As we can see, non-response rates of $30 \%$ are common, thus the findings from the literature are based on the $70 \%$ of people who typically agree to participate.

It is important that we are cognisant of the above issues when interpreting the findings of CSA studies. As Pereda, Guilera, Forns \& Gomez-Benito (2009) note, following their review of 39 prevalence studies across 28 countries and five continents, difficulties remain in reaching a consensus on the definition of child maltreatment and sexual abuse (Manly, 2005, cited in Pereda et al., 2009). For the purpose of this review, studies that refer to CSA, with or without behaviourally specific definitions, will be included. Where authors have clarified their definition of CSA, this will be referred to wherever possible. The objective of this review is to be inclusive, acknowledging the limitations of this approach.

\section{Child Sexual Abuse Prevalence Worldwide}

As noted above, there is a growing body of well-designed studies from around the world published in international peer-reviewed journals. An exhaustive review is beyond the scope of this paper. Instead, a geographically diverse selection of studies carried out in recent years will be briefly presented in Table 1 below:

Table 1: 'Headline' findings on child sexual abuse

\begin{tabular}{|c|c|c|c|}
\hline Country & Study & Incidence & Perpetrators \\
\hline $\mathrm{UK}$ & $\begin{array}{l}\text { May-Chahal } \\
\text { \& Cawson } \\
(2005), \\
n=286918- \\
24 \text { yr olds }\end{array}$ & $\begin{array}{l}10 \% \text { ( } 6 \% \text { male; } 15 \% \text { female) reported a } \\
\text { form of contact child sexual abuse before } \\
\text { age } 16 \\
2 \% \text { (1\% male; } 3 \% \text { female) reported } \\
\text { sexual intercourse against their wishes } \\
\text { before age } 16\end{array}$ & $\begin{array}{l}1 \% \text { of the total sample reported } \\
\text { contact csa by parent/carer; } 2 \% \\
\text { reported contact csa by relative; } \\
8 \% \text { reported contact csa by } \\
\text { other known person; } 2 \% \\
\text { reported contact csa by } \\
\text { stranger/person just met }\end{array}$ \\
\hline France & $\begin{array}{l}\text { King et al. } \\
(2006), \\
n=12,256 \\
\text { adults }\end{array}$ & $\begin{array}{l}1.3 \% \text { ( } 0.7 \% \text { male; } 2.1 \% \text { female) a 'forced } \\
\text { sexual relationship ('touching' or } \\
\text { 'attempted rape' or 'rape') before age } \mathbf{1 8}\end{array}$ & Not reported \\
\hline Ireland & $\begin{array}{l}\text { McGee et al. } \\
(2002) \text {, } \\
n=\text { random } \\
\text { sample of } \\
3,118 \text { adults }\end{array}$ & $\begin{array}{l}\text { Females: } 20.4 \% \text { contact sexual abuse } \\
\text { before age } 17,5.6 \% \text { penetrative abuse } \\
\text { before age } 17 \\
\text { Males: } 16.2 \% \text { contact sexual abuse before } \\
\text { age } 17,2.7 \% \text { penetrative abuse before } \\
\text { age } 17\end{array}$ & $\begin{array}{l}\text { Against females: } 24 \% \text { family } \\
\text { members; } 52 \% \text { known to } \\
\text { victim; } 24 \% \text { strangers } \\
\text { Against males: } 14 \% \text { family } \\
\text { members; } 66 \% \text { known to } \\
\text { victim; } 20 \% \text { strangers }\end{array}$ \\
\hline
\end{tabular}




\begin{tabular}{|c|c|c|c|}
\hline China & $\begin{array}{l}\text { Chen et al. } \\
(2004), \\
\mathrm{n}=2,300 \\
\text { high school } \\
\text { students }\end{array}$ & $\begin{array}{l}\text { Females: } 16.7 \% \text {, 'unwanted sexual } \\
\text { experience' before age } 16 \text { ( } 6.5 \% \text { touching } \\
\text { or fondling; } 0.3 \% \text { unwanted sexual } \\
\text { intercourse) } \\
\text { Males: } 10.5 \% \text {, 'unwanted sexual } \\
\text { experience' before age } 16 \text { ( } 2.8 \% \text { touching } \\
\text { or fondling; } 0.1 \% \text { unwanted sexual } \\
\text { intercourse) }\end{array}$ & Not reported \\
\hline $\begin{array}{l}\text { Bedouin- } \\
\text { Arabs in } \\
\text { Southern } \\
\text { Israel }\end{array}$ & $\begin{array}{l}\text { Elbedour et } \\
\text { al. (2006), } \\
\mathrm{n}=217 \\
\text { female } \\
\text { adolescents }\end{array}$ & $\begin{array}{l}31 \% \text { some form of child sexual abuse } \\
\text { between the ages of } 14 \text { and } \mathbf{1 8} \\
13 \% \text { fondling; } 4 \% \text { penetrative abuse }\end{array}$ & $\begin{array}{l}\text { Limited data provided. } 16 \% \\
\text { strangers }\end{array}$ \\
\hline $\begin{array}{l}\text { New } \\
\text { Zealand }\end{array}$ & $\begin{array}{l}\text { Fanslow et } \\
\text { al. }(2007) \\
\mathrm{n}=2,855 \\
\text { females }\end{array}$ & $\begin{array}{l}23.5 \% \text { in the urban (Auckland) area and } \\
28.2 \% \text { of women in the rural (Waikato) } \\
\text { region 'sexually touched or made to do } \\
\text { something sexual they did not want to' } \\
\text { before age } \mathbf{1 5}\end{array}$ & $\begin{array}{l}86 \% \text { male family members } \\
1 \% \text { described as 'strangers' }\end{array}$ \\
\hline USA & $\begin{array}{l}\text { Briere and } \\
\text { Elliott } \\
(2003) \\
n=\text { national } \\
\text { sample of } \\
935 \text { adults }\end{array}$ & $\begin{array}{l}32.3 \% \text { of females and } 14.2 \% \text { of males, at } \\
\text { least one episode of childhood sexual } \\
\text { abuse (kissed or touched in a sexual way) } \\
\text { before } 18 \text {. } \\
52.8 \% \text { of child abuse incidents involved } \\
\text { penetrative abuse }\end{array}$ & $\begin{array}{l}46.8 \% \text { 'incest' } \\
\text { Against females: } 93 \% \text { by at } \\
\text { least one male; } 9 \% \text { by at least } \\
\text { one female } \\
\text { Against males: } 39 \% \text { by at least } \\
\text { one female, } 70 \% \text { by at least one } \\
\text { male }\end{array}$ \\
\hline Swaziland & $\begin{array}{l}\text { CDCP \& } \\
\text { Unicef } \\
(2007) \\
\mathrm{n}=1,920 \\
\text { females } \\
\text { aged } 13-24 \\
\text { years }\end{array}$ & $\begin{array}{l}33.3 \% \text {, some form of sexual violence } \\
\text { before age } \mathbf{1 8} \\
9.1 \% \text { 'coerced intercourse' before age } \\
\mathbf{1 8} \\
4.9 \% \text { 'forced intercourse' before age } \mathbf{1 8}\end{array}$ & $\begin{array}{l}35.6 \% \text { husband or boyfriend, } \\
27.1 \% \text { a man/boy from the } \\
\text { victim's neighbourhood, } 15.7 \% \\
\text { a male relative other than a } \\
\text { father, stepfather or husband, } \\
10.1 \% \text { a stranger }\end{array}$ \\
\hline Ethiopia & $\begin{array}{l}\text { Worku et al. } \\
(2006), \mathrm{n}= \\
323 \text { female } \\
\text { secondary } \\
\text { school } \\
\text { students } \\
\text { (aged } 12 \text { to } \\
20 \text { years) }\end{array}$ & $\begin{array}{l}68.7 \% \text {, some form of sexual abuse 'in } \\
\text { their lifetime' } \\
18.1 \% \text { unwanted sexual intercourse }\end{array}$ & $\begin{array}{l}36 \% \text { strangers, } 31.5 \% \text { school } \\
\text { mates, } 16.7 \% \text { family members } \\
\text { (comprising } 1.4 \% \text { father, } 9.3 \% \\
\text { step father, } 2.3 \% \text { elder brother, } \\
0.9 \% \text { uncle, } 5 \% \text { other family } \\
\text { members) and } 15.8 \% \\
\text { neighbours }\end{array}$ \\
\hline Tanzania & $\begin{array}{l}\text { McCrann, } \\
\text { Lalor and } \\
\text { Katabaro } \\
(2006) \\
\text { n=487 } \\
\text { university } \\
\text { students }\end{array}$ & $\begin{array}{l}27 \% \text { of the sample ( } 31 \% \text { of females and } \\
25 \% \text { of males) one or more unwanted } \\
\text { sexual experiences before the age of } \mathbf{1 8} \text {. } \\
\text { Females: unwanted fondling, } 27.9 \% \text {; } \\
\text { sexual intercourse, } 11.2 \% \text {; oral sex, } 5.6 \% \\
\text { Males: unwanted fondling, } 13.4 \% \text {; sexual } \\
\text { intercourse, } 8.8 \% \text {; oral sex, } 6.2 \%\end{array}$ & Limited data provided \\
\hline $\begin{array}{l}\text { South } \\
\text { Africa }\end{array}$ & $\begin{array}{l}\text { Jewkes et al. } \\
(2002) \text {, } \\
n=11735\end{array}$ & $\begin{array}{l}1.6 \%, \text { forced or persuaded to have sex } \\
\text { against their will before age } 15 .\end{array}$ & $\begin{array}{l}33 \% \text { school teachers, } 21 \% \\
\text { relations, } 21 \% \text { strangers or } \\
\text { recent acquaintances, } 10 \%\end{array}$ \\
\hline
\end{tabular}




\begin{tabular}{|l|l|l|l|}
\hline & $\begin{array}{l}\text { women aged } \\
15-49 \text { years }\end{array}$ & $\begin{array}{l}3 \% \text { of 15-19 year olds, forced or } \\
\text { persuaded to have sex against their will } \\
\text { before age 15. }\end{array}$ & boyfriends \\
\hline
\end{tabular}

As we can see, rates for penetrative CSA are higher for girls than for boys. For female children/adolescents, rates for penetrative abuse range from $0.3 \%$ (China); between $1.6 \%$ and 3\% (South Africa); 4\% (Israel); 5.6\% (Ireland); 11\% (Tanzania); to a high of 18\% reporting 'unwanted sexual intercourse' in one Ethiopian study.

Data on perpetrators are not always reported, but the studies above show that (for all types of CSA) 'strangers' make up only a minority of perpetrators. For example, $1 \%$ (New Zealand); 2\% (UK); 10\% (Swaziland); 16\% (Israel); 21\% (strangers and recent acquaintances) (South Africa); 36\% (Ethiopia).

Accordingly, very high proportions of perpetrators were well known to the child; $86 \%$ were family members in the New Zealand study described above; $76 \%$ of perpetrators were family members or known to the child (Ireland); $78 \%$ were boyfriends, neighbours or a male relative (Swaziland); and, in South Africa, 64\% were teachers, relatives or boyfriends.

These findings should not be seen as comparisons in prevalence across countries, due to differences in study design, definitions and sampling.

\section{WHO Multi-Country Study}

In addition to the individual studies mentioned above, a recent multi-country study is important to note. García-Moreno, Jansen, Ellsberg, Heise and Watts (2005) report on a WHO multi-country study on women's health and domestic violence, including experiences of childhood sexual abuse. The report contains data from more than 24,000 survey respondents in 10 countries. This represents one of the largest scale studies of women's experiences of CSA (and other forms of violence) worldwide.

Results regarding CSA (defined as someone touching them sexually, or making them do something sexual they did not want to, before the age of 15) and the identity of perpetrators are shown in Table 2 below.

Table 2: Incidence and perpetrators of childhood sexual abuse against females (Source: García-Moreno et al., 2005)

\begin{tabular}{|l|l|l|l|l|l|}
\hline Location & $\begin{array}{c}\text { \% reporting } \\
\text { SA before age } \\
\mathbf{1 5}^{\mathbf{1}}\end{array}$ & Family $^{\mathbf{2}}$ & Acquaintance $^{\mathbf{3}}$ & Stranger $^{4}$ & $\begin{array}{c}\text { Not } \\
\text { identified }\end{array}$ \\
\hline Bangladesh city & 7.4 & 10.9 & 14.3 & 69.7 & 5.9 \\
\hline Bangladesh province & 1 & $*$ & $*$ & $*$ & $*$ \\
\hline Brazil city & 11.6 & 66.3 & 14.1 & 8.7 & 14.1 \\
\hline Brazil province & 8.7 & 54.1 & 30.6 & 12.9 & 11.8 \\
\hline Ethiopia province & 7 & $*$ & $*$ & $*$ & $*$ \\
\hline Japan city & 13.8 & 9.2 & 20.6 & 69.5 & 5.3 \\
\hline Namibia city & 21.3 & 46.6 & 34.2 & 16.4 & 4.1 \\
\hline
\end{tabular}




\begin{tabular}{|l|l|l|l|l|l|}
\hline Peru city & 19.5 & 53.6 & 16.7 & 25 & 19.2 \\
\hline Peru province & 18.1 & 41.4 & 20 & 22.8 & 24.1 \\
\hline Samoa & 1.8 & 23.3 & 33.3 & 33.3 & 16.7 \\
\hline Serbia and Montenegro city & 4.2 & 28.6 & 25 & 39.3 & 10.7 \\
\hline Thailand city & 8.9 & 7.7 & 12 & 58.1 & 24.8 \\
\hline Thailand province & 4.9 & 21.7 & 11.7 & 30 & 38.3 \\
\hline $\begin{array}{l}\text { United Republic of } \\
\text { Tanzania city }\end{array}$ & 12.2 & 27.8 & 29.1 & 13.9 & 32.9 \\
\hline $\begin{array}{l}\text { United Republic of } \\
\text { Tanzania province }\end{array}$ & 9.5 & 18.3 & 41.7 & 18.3 & 28.3 \\
\hline
\end{tabular}

The researchers asked questions related to child sexual abuse in face-to-face interviews, and by asking them to anonymously mark a card. In some regions, this produced quite different results. The results presented here are the researchers' 'best estimate' of true incidence.

2 'family' includes father, step-father, male and female family members.

${ }^{3}$ teacher, friend of family, boyfriend, someone at work, religious leader.

${ }^{4}$ Includes police/soldier.

* \% based on less than 20 respondents suppressed.

There are a number of important patterns to note here. Firstly, the percentage of respondents reporting CSA varies widely worldwide, from a high of $21.3 \%$ in Namibia 'city', to a low of $1 \%$ in Bangladesh 'province'. More research is needed to determine the risk and protection factors at work here.

It is also interesting to note the variance between these figures and some of the other studies we have looked at earlier. For example, Table 2 above shows that $7 \%$ of the sample in Ethiopia 'province' reported 'being touched sexually or being made to do something sexual they did not want to do' before age 15 years. We saw earlier that Worku et al. (2006) reported that a sample of 12 to 20 year old Ethiopian schoolgirls reported a very high proportion (18\%) experiencing unwanted sexual intercourse 'in your lifetime'. Clearly, the age cut-off of 15 in the WHO study will show lower prevalence rates relative to other studies on CSA, which typically use a higher cut off age (typically, before age 18).

Also of note is the identity of perpetrators. It is difficult to see any pattern here. In some regions, family members and acquaintances accounted for the bulk of the abuse $(80.4 \%$ in Brazil 'province'; 84.7\% in Brazil 'city'; 80.8\% in Namibia). By comparison, in Thailand 'city', family and acquaintances only accounted for $19.7 \%$ of perpetrators.

In some regions, 'strangers' are significant abusers (69.7\% in Bangladesh 'city' and $69.5 \%$ in Japan 'city'). By contrast, they account for only $8.7 \%$ of abusers in Brazil 'city'.

Prevalence rates noted in this table are comparable to those cited in Finkelhor (1994) and a follow up review conducted by Pereda et al. (2009). In both reviews, the majority of studies (67 and 50\% respectively) report prevalence rates for sexual abuse of male children of below $10 \%$ while in the case of females most studies (38 and 34\% respectively) locate the prevalence between 10 and 20\%. Another $29 \%$ of studies in both reviews, report a prevalence rate of CSA among women of between 30 and 40\%. Many of the studies reviewed defined CSA as either contact or non-contact sexual experiences 
between a person under 18 years of age and an adult or other person at least five years older or sexual experiences resulting from coercion, regardless of the age of the other person.

\section{What is the Link between Child Sexual Abuse and Later Sexual Exploitation?}

The purpose of this section is to describe the sequelae of CSA. First, general mental health sequelae are briefly described. The remainder of this section focuses on the link between CSA and later sexual revictimization. The link between CSA and high-risk sexual behaviour is also considered.

\section{The Negative Sequelae of Child Sexual Abuse}

Child sexual abuse (CSA) includes a broad range of behaviours, which can be perpetrated across a broad range of intrafamilial and extrafamilial relationships, and there is considerable variability in the duration and frequency of the abuse (Paine \& Hansen, 2002). This multi-faceted nature accounts for the heterogeneity of children's reactions to abuse, ranging from severe psychological impact to no evidence of negative psychological sequelae (Kendall-Tackett, Williams \& Finkelhor, 1993).

Citing various reviews (for example, Briere \& Runtz, 1993; Finkelhor, 1990; Polusny \& Follette, 1995), Briere and Elliott (2003) summarise two decades of research which:

suggest with relative unanimity that childhood physical and sexual abuse have a wide number of psychological sequelae. Among these are low self-esteem, anxiety, depression, anger and aggression, post-traumatic stress, dissociation, substance abuse, sexual difficulties, somatic preoccupation and disorder, selfinjurious or self-destructive behavior, and most of the various symptoms and behaviours seen in those diagnosed with borderline personality disorder (p. 1207).

For example, Dube et al. (2005) surveyed 17,337 adult members of a health plan in California regarding childhood experiences and current health and social problems. Overall, $16 \%$ of male respondents and $25 \%$ of females reported some type of contact sexual abuse before age 18 . The results showed a markedly greater likelihood of social/health problems in adulthood amongst CSA victims, for both women and men. Victims were several times more likely to have alcohol problems, use illicit drugs, attempt suicide and have current marriage/family problems.

Severity of CSA (penetrative vs. non-penetrative) is associated with elevated risk of social or health problems in adulthood. The authors conclude "exposure to CSA among both genders is common, and acts as a strong risk factor for multiple types of mental health, behavioral, and social outcomes similarly for adult men and women" (Dube et al., 2005, p. 434).

It is important to note that a significant proportion of children do not experience psychopathology following sexual abuse. Collishaw et al. (2007) report on data from the 
longitudinal Isle of Wight study in the UK. Approximately $10 \%$ of respondents (now in middle age, 44-45 years) reported having experienced physical or sexual abuse in childhood while about $8 \%$ reported severe or repeated physical or sexual abuse. Of those reporting abuse, a substantial percentage (around 45\%) reported no psychopathology over their adult lives. The authors attribute this to factors such as parental care, peer relationships in adolescence, personality, and the quality of adult relationships.

\section{Link between Child Sexual Abuse and Sexual Revictimization}

In addition to socio-emotional and mental health sequelae, numerous studies have also highlighted that CSA victims are vulnerable to later sexual revictimization. Most studies do not distinguish between intra and extrafamilial CSA. Rather, they seek to investigate effects in adulthood, or correlates, of any form of childhood sexual, physical or emotional maltreatment.

An early study was conducted by Russell (1986) who found that $63 \%$ of a sample of women who experienced intrafamilial sexual abuse before age 14, also experienced rape or attempted rape after age 14 (compared to $35 \%$ of those who did not report childhood sexual abuse), suggesting that childhood sexual abuse doubled the risk of sexual revictimization. Research over the past decade has consistently replicated Russell's findings with rates of victimization varying from study to study, ranging from $13.7 \%$ (Humphrey \& White, 2000) to 27\% (McGee et al., 2002). Classen, Palesh and Aggarwal (2005) reviewed approximately 90 empirical studies and concluded that CSA is a significant risk factor for sexual revictimization. Messman-Moore and Long's (2003) review found that CSA survivors are between 2 and 11 times more likely to experience adult assault compared to non-victims. Steel \& Herlitz' (2003) study in Sweden of 2,810 adults found that those men and women who had experienced child or adolescent sexual abuse were at higher risk for adult sexual assault (8\% vs. $1 \%$ ).

Roodman and Clum (2001) reviewed 19 empirical studies of females where at least one incidence of childhood sexual abuse was followed by a subsequent incident of adult sexual victimization. They found an effect size for revictimization of .59 and that the effect size varied from very low to very high, reflecting the variety of methods and definitions used. For example, those studies with an older average sample age showed a larger effect size (not surprisingly, as participants have had more time in which to be revictimized). The definitions of child and adult abuse were also found to be important. The effect size average for studies using broad definitions of child abuse was .38. This increased to .64 for those studies utilizing a 'contact' sexual abuse definition. McGee et al's (2002) high rate of $27 \%$ was based on penetrative CSA and penetrative sexual violence in adulthood. However, the risk of contact non-penetrative violence was $24 \%$ as compared with respective risks of $10 \%$ (penetrative) and $3 \%$ (contact non-penetrative) for those with no experience of abuse in childhood.

Sexual revictimization in adolescence appears to significantly increase the risk of sexual assault in adulthood. Humphrey and White (2000) report on a five-year longitudinal study of sexual assault among a sample of 1569 female college students. They found that victims of childhood assault were significantly more likely to experience either moderate 
('unwanted or verbal coercion') or severe ('attempted or completed rape') adolescent victimization than non-victims. Respondents who had an experience of rape or attempted rape in their adolescent years were 13.7 times more likely to experience rape or attempted rape in their first year of college

Classen, Palesh and Aggarwal (2005) point out that more severe forms of CSA, and the co-existence of physical abuse, increase the risks for later revictimization. They also found that sexually abused children were more likely to be abused as adolescents; who were in turn more likely to be sexually revictimised as adults. Widom, Czaja and Dutton (2008) report the findings of a prospective study of children physically and sexually abused between 1967 and 1971, and a comparison group of nonabused children matched for sex, age race and socioeconomic status. Both groups were followed up and interviewed between 2000 and 2002 (at a mean age of 39.5 years). Those who experienced abuse / neglect in childhood had significantly higher rates of sexual assault / abuse in adulthood (47.7\% vs. $28.6 \%)$.

Some studies report whether the revictimization in adulthood is perpetrated by a partner or a non-partner, influencing risk rates. Fanslow et al.'s (2007) New Zealand study of 2,855 women found that women who reported childhood sexual abuse were three and a half times more likely to report sexual violence by a non-partner in their lifetime $(23.2 \%$ vs. 6.4\%). In Dunkle et al.'s (2004b) sample of 1395 women attending antenatal clinics in South Africa, $74.8 \%$ reported physical / sexual partner violence and $15.6 \%$ reported adult sexual assault by a non-partner. The equivalent prevalence for participants who did not report child sexual assault or forced first intercourse was $52.2 \%$ and $5.3 \%$, respectively.

As is the case with prevalence rates of CSA, differences have also been found between men and women in revictimization risk rates. McGee et al. (2002) found that women had an $11 \%$ and $12 \%$ higher risk of penetrative and contact non-penetrative sexual violence respectively than men in their study.

The research is not unequivocal in establishing the link between sexual victimization in childhood and later sexual assault. Mandoki and Burkhart (1989) examined the relationship between child and adult sexual victimization among a sample of 282 female undergraduates (mean age 19.5 years). Unlike much of the research in this area, they found that those sexually victimized as children were not more likely than non-victims to be sexually assaulted as adults.

\section{Link between Child Sexual Abuse and High-Risk Sexual Behaviour}

In addition to the link between CSA and revictimization, numerous studies have examined the relationship between CSA and later engagement in high-risk sexual behaviour (such as having multiple sexual partners), prostitution and sexual promiscuity.

Fergusson, Horwood and Lynskey (1997) studied a birth cohort of 520 females in New Zealand from birth to age 18. They found clear correlations between CSA and high-risk sexual behaviours. For example, $58.6 \%$ of those who had experienced penetrative CSA had more than five sexual partners before age 18 , compared to $13.3 \%$ who reported no 
form of CSA. Zierler et al., 1991 found that men and women who had been raped or forced to have sex as a child or teenager were twice as likely to have had multiple partners than those who were not assaulted. Other high risk sexual behaviours found to be significantly more common in their abused sample included changing partners frequently, and engaging in sex with casual acquaintances. Krahé et al. (1999, cited in MessmanMoore and Long, 2003) found that the number of partners predicted sexual victimization, with women who reported CSA having had a significantly higher number of partners (average of 5.6 vs. 2.9 reported by women without histories of CSA), which was in turn related to higher rates of later victimization. Steel \& Herlitz, (2005) found that victims of child or adolescent sexual abuse were at higher risk of: engagement in group sex compared to a sample of adults who had not experienced such abuse (12\% vs. $6 \%$ ).

Unprotected sexual intercourse has also been found to be significantly more prevalent in young women reporting CSA (Fergusson et al., 1997). Sexually transmitted diseases are an obvious concern when considering multiple sex partners and unprotected sex. Wingood and DiClemente (1997) found that in their sample of 165 female African Americans in a socioeconomically deprived area of San Francisco, 13.3\% had experienced forced sex before the age of 16. This group were 1.4 times more likely to report having a sexually transmitted disease, and 2.4 times more likely to report having more than two lifetime sexually transmitted diseases.

Early onset of consensual sexual activity has been associated with a history of CSA in women, (Fergusson et al., 1997; Noll, Trickett and Putnam, 2003). In Noll et al.'s study, the average age of first voluntary intercourse in their female sample was 14 years, compared to 15.5 years in their matched comparison group. Early age at first intercourse has also been found to be associated with a history of child and adolescent abuse in Sweden (Steel \& Herlitz, 2005) and China (Chen et al., 2004). Steel \& Herlitz' study of 2,810 adults found that $61 \%$ of child and adolescent sexual abuse (CASA) victims reported first intercourse prior to 17 years, compared to $42 \%$ of non-CASA victims. Related to this, teenage pregnancy has also been found to be more prevalent in studies of women (Fergusson et al., 1997). Zierler et al. (1991) found that women in their study were two and a half times more likely to have become pregnant as a teenager than those who were not sexually assaulted as a child or teenager.

Prostitution has been found to be more prevalent in studies of both women and men who experienced penetrative abuse in childhood or adolescence (Zierler et al., 1991; Steel \& Herlitz, 2005). In Zierler et al's study, women were four times more likely to report having worked as a prostitute. Widom and Kuhns (1996) found childhood sexual abuse to be a significant predictor of prostitution in female subjects. Overall, $10.73 \%$ of their abuse/neglect group had engaged in prostitution, compared to $5.6 \%$ of the control group. For females, the difference between the abuse/neglect group and the control group were $8.93 \%$ vs. $2.87 \%$, and for males it was $12.54 \%$ vs. $8.03 \%$. Potter, Martin and Romans (1999) compared a group of 29 prostitutes, with a sample of similarly aged females from the general population. The former were significantly more likely than the latter to have experienced penetrative sexual abuse before age 16 (25\% vs. $4.7 \%)$.

Bagley and Young (1987) found that $73 \%$ of former prostitutes had experienced CSA compared to $29 \%$ of a control group from the general population. The former were 
significantly more likely to report penetrative sexual abuse before age 16 (25\% vs. $4.7 \%$ ). Furthermore, they found the sexual abuse experienced by the prostitute group was more frequent and serious in nature, involved more serious assault, more often involved different individuals, began at a significantly earlier age and continued for longer. They also found that $71 \%$ of the former prostitutes had 'devastated self-esteem' compared to $7 \%$ of the control group.

It cannot be said, however, that CSA causes later high risk behaviours and revictimization. There may be other mediating factors (such as parental conflict, parental psychopathology) that are associated with sexual abuse experiences and high risk behaviour and/or victimization.

Both the Widoms \& Kuhn (1996) study and the Noll et al., (2003) study were prospective studies from early childhood to early adulthood over a ten year period, using matched comparison groups. The former study involved a sample size of 82 in the abused group and 84 in the matched control group while the latter study had a sample of 1196 subject (676 abused and/or neglected and 520 control subjects). Noll et al. (2003) also used an explicit definition of CSA, a well-matched comparison group and they succeeded in retaining over $95 \%$ of the sample. A prospective design allows the effects of sexual abuse to be 'disentangled' from other potential sources of trauma, such as poverty, and chaotic family background.

\section{Mediating Factors in the Link between Childhood Sexual Abuse and Revictimization and High Risk Sexual Behaviours}

Respondents in Fergusson et al's study reporting CSA were significantly more likely to come from disturbed family/home environments, characterised by instability, physical punishment, poor parental attachment, and use of illicit drugs/alcohol. Similarly, Potter, et al. (1999) found significant differences between their prostitute group and their control group regarding parental separation (38\% of the prostitute group, compared to $8.5 \%$ of the control group). However, the association between CSA and variables such as multiple partners, unprotected intercourse, consensual intercourse before age 16 and rape/attempted rape remained statistically significant even allowing for these family variables. Fergusson et al. (1997) conclude that such findings suggest a possible cause and effect link in which CSA leads to increased sexual risk taking in adolescence, to early onset of sexual intercourse.

Widoms and Kuhn (1996) speculate that running away and being alone on the streets and thus being vulnerable to pimps and pornographers may contribute to the links found between childhood sexual abuse and later high risk sexual behaviours. Potter, et al. (1999) compared the family backgrounds of 29 prostitutes, with a sample of similarly aged females from the general population. The former were significantly more likely than the latter to have experienced penetrative sexual abuse before age 16 (25\% vs. $4.7 \%)$. the sex worker group were considerably more likely to leave home early (55\% had left home by age 17 , compared to $26 \%$ in the general population).

Widoms and Kuhn note the lack of attention in the research to separating out the effects directly related to sexual abuse from those possibly due to pre-existing difficulties for the 
child, the family or the stress associated with disclosure so that the unique contribution of childhood abuse and neglect can be realised.

Fergusson and Mullen (cited in Fleming, Mullen, Sibthorpe \& Blammer, 1999) note that the influence of a positive family environment operates at two levels. Firstly in facilitating the development of the child in terms of resilience and secondly in providing a nurturing and supportive environment in which the child can recover from the impact of the abuse and re-establish the security needed for normal development.

Noll, Trickett and Putnam (2003) suggest that stigmas associated with childhood sexual abuse " may result in an inability to glean nonsexual or emotional rewards from relationships, therefore placing victims in potentially risky or exploitative sexual situations" (p. 582).

Stoltz et al. (2007) found a significant relationship between child maltreatment (sexual, physical and emotional) and later involvement in prostitution among a sample of 361 drug-using street-involved youth in Vancouver, Canada. They suggest two explanations for this relationship. Firstly, those children who are sexually victimised "develop psychologically and emotionally in ways that make them vulnerable to continuing sexual predation". Secondly, they speculate that "childhood sexual abuse may create a propensity in the victim toward risk-taking behavions (substance abuse, running away from home) ... that in turn lead to situations in which survival sex work is one of few remaining options" (p. 1218).

Stoltz and colleagues offer similar explanations for the susceptibility of emotionally abused youth to become involved in trading sex, thus emphasising that CSA in and of itself does not 'cause' later involvement in prostitution. Rather, it is a component of a generally traumatic, negative developmental experience.

Nevertheless, numerous studies report that juvenile prostitutes identify the sexual abuse they experienced as a child as a major factor in their decision to become involved in prostitution. For example, 70\% of the subjects in Silbert and Pines' (1982) in the US and $62 \%$ of those in Bagley and Young's (1987) study in Canada reported that childhood sexual abuse affected their decision to become involved in prostitution. However, there is no evidence that any but a small proportion of children who are sexually victimized subsequently become involved in trading sex for money or goods. In other words, while Flowers (1998) can maintain that "nearly all girl prostitutes have been sexually molested, assaulted, or physically abused before entering the profession" (p. 82), the reverse does not hold. In Sweden, Steel and Herlitz (2005) found that $1 \%$ of the sample of 268 child and adolescent sexual abuse victims reported having engaged in 'sex work', compared to $0 \%$ of the sample of 2625 non- victims. This does not suggest a strong pre-disposition to involvement in prostitution amongst child and adolescent sexual abuse victims.

In one African study, Slonim-Nevo and Mukuka (2007) surveyed 3,360 10-19 year olds in Zambia regarding their experiences of physical and sexual abuse by family members and Aids related knowledge, attitudes and behaviour. They found that abuse by family members was a significant predictor of engagement in high-risk behaviours. The higher the level of sexual and physical abuse in the family, the higher the probability was of engaging in high-risk behaviour. These findings were independent of various socio- 
demographic factors. They argue that intrafamilial abuse should not be ignored not only because of the negative impacts on the development of children, but because it also reduces the likelihood of them being able to protect themselves from HIV/AIDS. The cultural context in sub-Saharan Africa where violence/coercion in early sexual relationships and exchange sex is so prominent may mask the relationship between early abusive sexual experiences and later high risk behaviours such as multiple partners, exchange sex, prostitution and repeat sexual assaults and rape (Lalor, 2008).

\section{What are the Reasons for CSA Victims' Vulnerability to Later Revictimization and High-Risk Sexual Behaviour?}

The studies above do not always speculate as to why CSA victims are vulnerable to revictimization and risky sexual behaviour. As many studies into CSA and its effects are cross-sectional in design, it is not possible to identify causal factors. Numerous mediating variables have been proposed, such as low self-esteem, alcohol use, dissociation, low danger awareness, and social isolation.

\section{Possible explanations for the revictimization of child sexual abuse victims}

Cloitre's socio-developmental approach (1998, cited in Arata, 2002) proposes that abuse in childhood interferes with the development of affect regulation and interpersonal relatedness, which in turn impacts on women's awareness of danger and ability to respond to threatening situations. Gold, Sinclair and Balge's model (1999, cited in Arata, 2002) suggests that CSA leads to impairments in attachment, psychological symptoms and negative attributes and coping behaviours, resulting in behaviours that increase the risk of rape.

Polusny and Follette (1995) proposed a conceptual model based on the theory of 'emotional avoidance'. From this perspective, many of the long term correlates of CSA are the individual's efforts to minimize or reduce negative emotional states such as guilt, shame, fear and rage, and associated thoughts and memories. Over time, emotional avoidance behaviours (such as dissociation, substance abuse and self-mutilation) "are negatively reinforced by the reduction or suppression of the intense affective responses associated with sexual abuse experiences" (p. 158). In this context, high-risk sexual behaviours (such as frequent, indiscriminate, compulsive sexual behaviours) serve to modulate emotional pain by providing more pleasurable, distress-incompatible input (Briere \& Runtz, 1993, cited in Polusny \& Follette, 1995). This emotional avoidance may lead to revictimization. For example, chronic dissociative coping behaviours may lead survivors to ignore or minimize social cues in dangerous adult situations (Walker et al., 1992, cited in Polusny \& Follette, 1995). Sandberg, Matorin and Lynn (1999, cited in Messman-Moore \& Long, 2003) note the high levels of Post Traumatic Stress Disorder (PTSD) amongst CSA survivors and suggest this can interfere with information processing of danger cues.

Steel and Herlitz (2005) hypothesize a possible pathway from child and adolescent sexual abuse (CASA) to sexual risk behaviour, with psychological symptoms/disorders as a mediator. Psychological sequelae to CASA, such as depressive symptoms, poor self- 
esteem, lack of assertiveness, poor self-worth, PTSD, may lead to future risk behaviour due to "(1) feelings of unworthiness; (2) the inability to be assertive and prevent unwanted sexual advances; (3) avoidance or inability to comprehend emotionally laden information concerning sexuality; or (4) having competing needs for affection and acceptance" (p. 1150). They conclude, "future research is warranted to both understand the mechanisms underlying the relationship between CASA and SRBs and to explore other childhood and adolescent experiences that may predict SRBs as an adolescent or adult" (p. 1151).

Slonim-Nevo and Mukuka (2007) also speculate as to the mediating variables that link intrafamilial CSA and engagement in HIV-risk sexual behaviour, they note:

Depression and other psychological problems may lead adolescents to a sense of hopelessness and futility about living. Such a perspective may thus lead to a sense of indifference about sickness and even death. Consequently, these adolescents engage in immediately satisfying sexual activities and fail to protect their future" (p. 156).

There is some empirical support for the role of dissociation as a mediating variable. Meadows, Jaycox, Orsillo and Foa (1997, cited in Messman-Moore and Long, 2003) suggest that withdrawing from potentially harmful situations may be due to difficulties in risk recognition and acting on potential risk. They found no difference between previously victimized and non-victimized women (physical or sexual assault at any age) for risk recognition. However, the previously assaulted group reported that they would leave a hypothetical scenario (or 'scene') significantly later than individuals with no history of assault:

Scenes with an acquaintance or someone known to the subject (rather than a stranger) were 'left' significantly later by subjects with a history of assault. Further, subjects without a history of assault also endorsed leaving the scene prior to physical contact, in contrast to previously abused subjects who usually did not endorse leaving until after physical contact had been made (Meadows et al., 1997, cited in Messman-Moore and Long, 2003, p. 550).

Many authors emphasize the need for prospective studies to enquire into the causal pathways from childhood sexual abuse to revictimization (Sanders \& Moore, 1999; Arata, 2000; 2002). Messman-Moore and Long (2003) argue for a shift of focus from the victim to interpersonal and cultural factors within society:

"Our theories of revictimization will shape what we will find empirically. If we focus on the victim, we will find within her and her behavior explanations for revictimization ... We will never fully understand revictimization while the microscope remains focused solely on the victim" (p. 566).

Grauerholz (2000) proposes an ecological model to explain child sex abuse victims' increased risk of being sexually victimised later in life. The focus is on female victims as 
"research on male sexual revictimization is nonexistent" (p. 5). She notes that explanations frequently focus on individualistic factors, facilitating a 'victim-blaming' interpretation; she argues that a comprehensive explanation must incorporate interpersonal and socio-cultural factors. After Bronfenbrenner (1979) and Belsky (1980), an ecological perspective is proposed which incorporates ontogenic development (one's individual personal history), the microsystem (for example, family relations), the exosystem (larger social systems in which the individual or family is located) and the macrosystem (cultural norms and institutions). Thus, a rich contextual understanding is gained of the individual, interpersonal, community and societal forces causing repeat sexual victimization. Grauerholz (2000) proposes a range of factors hypothesised to be mediating variables between childhood sexual abuse and later sexual exploitation (revictimization).

Table 3: Factors hypothesised to be related to sexual revictimization

\begin{tabular}{|c|c|}
\hline $\begin{array}{l}\text { Ecological } \\
\text { Level }\end{array}$ & Factor (or variable) \\
\hline $\begin{array}{l}\text { Ontogenic } \\
\text { development }\end{array}$ & $\begin{array}{l}\text { The initial victimization experience (possible effects include traumatic } \\
\text { sexualisation, alcohol and drug abuse, dissociative disorders, low } \\
\text { self-esteem, powerlessness, stigmatization, learned expectancy for } \\
\text { victimization, social isolation, running away from home, deviance, } \\
\text { and early/pre-marital pregnancy } \\
\text { Early family experiences* (possible correlates include family breakdown, } \\
\text { disorganization and dysfunction, marital dysfunction, unsupportive } \\
\text { parents and patriarchal structure) }\end{array}$ \\
\hline Microsystem & $\begin{array}{l}\text { Exposure risk (factors increasing this risk include traumatic sexualisation, } \\
\text { dissociative disorder, alcohol abuse, involvement with deviant } \\
\text { activities, stigmatization, and low self esteem } \\
\text { Increased risk of perpetrator acting aggressively due to: } \\
\text { Perception of victim as easy target } \\
\text { Feeling justified in behaving aggressively } \\
\text { Victim's decreased ability to respond assertively and effectively to } \\
\text { unwanted sexual advances }\end{array}$ \\
\hline Exosystem & $\begin{array}{l}\text { Lack of resources (related factors include low socioeconomic status, unsafe } \\
\text { living conditions, early childbearing, single motherhood, and divorce } \\
\text { Lack of alternatives (due to weak family ties or support and social isolation) }\end{array}$ \\
\hline Macrosystem & $\begin{array}{l}\text { Cultural tendency to blame victim } \\
\text { Good girl/bad girl construction of femininity }\end{array}$ \\
\hline
\end{tabular}

*As noted by Messman-Moore and Long (2003), the original ecological model proposed by Bronfenbrenner conceived the family environment as part of the microsystem

Grauerholz (2000) notes the existence of a number of models or theoretical frameworks at the individual level that seek to explain how childhood sexual abuse affects a person's personality and behaviour in such a way that revictimization is facilitated: The traumatogenic model (Finkelhor and Browne, 1985); The post-traumatic stress model (Briere, 1997); Learning theory (Messman and Long, 1996, cited in Grauerholz, 2000).

According to Grauerholz, all these frameworks share a basic assumption that CSA can profoundly alter an individual's personality and social development. Research has shown that CSA victims exhibit traits of traumatic sexualisation such as earlier onset of sexual relations, greater numbers of partners and prostitution. Other factors include drug 
and alcohol abuse, low self-esteem, powerlessness and stigmatization. Grauerholz notes that the latter three factors have not been tested empirically.

Grauerholz also describes Messman and Long's (1996) 'learned expectancy' idea. It is suggested that women who have experienced sexual abuse as children "learn and adopt an inappropriate repertoire of sexual behaviour, and may learn to associate sexuality with pain, punishment, or other negative consequences" (Messman and Long, 1996, p. 399, cited in Grauerholz, 2000). Thus, such victims may learn that a degree of pain, coercion, and trauma is actually a normal aspect of sexual relations. Such a perspective would certainly give CSA victims a 'higher threshold of tolerance' for coercion, force, intimidation, pleading, lack of affection/regard in their later sexual relations.

The microsystem is the immediate (interpersonal) context in which revictimization occurs. Two ways a victim of CSA may become vulnerable to revictimization later in adulthood are suggested. "First, certain factors may lead to increased contact with potential perpetrators, contributing to an exposure risk. Second, certain factors may increase the likelihood that potential perpetrators with whom they come into contact will act aggressively" (Grauerholz, 2000, p. 10). Self-esteem, too, may play a role. Some CSA victims experience low self-esteem, which may lead to greater intimacies with potential abusers "in an effort to verify their self-image" (p. 10).

Aside from the victim, there may be factors that increase the likelihood of perpetrators acting aggressively; signals which lead them to believe their advances will be successful. For example, social isolation, low self-esteem, lack of family support systems, timidity, reluctance or inability to respond assertively to unwanted sexual advances.

The Exosystem level refers to those social systems in which the person in embedded (such as school, church, neighbourhood, extended family). Grauerholz invokes the concept of social power to suggest that CSA victims (who may become socioeconomically disadvantaged because of early pregnancy, less education, single parenthood, poverty) are relatively powerless at the exosystem level. Social isolation and poverty, for instance, may shape the opportunities a young female single parent perceives herself as having in terms of dating partners. She may also be less powerful in her intimate relationships and so be more vulnerable to violence from partners.

At the final, macrosystem, level Grauerholz considers the larger cultural context in which revictimization occurs. She suggests societal tendencies to 'blame the victim' of sexual assaults may facilitate later revictimization.

So, in plain terms, a proportion of victims of sexual abuse (not all) carry profound psychological distress into adulthood. This sadness, distrust, lack of confidence, low self-esteem makes a certain number vulnerable to revictimization and high risk sexual behaviour, including forms of commercial sexual exploitation, such as prostitution. A vulnerability to substance abuse enhances their risk of being assaulted or becoming involved in sex work. The experience of CSA appears to remove barriers to involvement in sex work for some victims. 


\section{Child Sexual Abuse: Prevention and Therapy}

This section will review the literature on both prevention and therapy in the CSA field.

\section{Prevention}

The literature on the prevention of sexual abuse advocates an ecological holistic approach which aims to address the various systemic levels that influence the child's development (Browne, Hanks, Stratton, \& Hamilton-Giachritsis, 2002; Save the Children Norway, 2005; WHO, 2002, 2004, 2006, 2007).

A proper prevention policy needs to include co-operation between the educational, health, social, child protection, police and judicial sectors and target not only children at risk but also the potential offender. A successful strategy has to attack the problem on different fronts in a holistic manner (Save the Children Norway, 2005, p.85).

Save the Children Norway (2005) describes several multi-sectoral initiatives from different continents and suggests that most governments have failed to take a central role in co-ordinating and implementing policies and services for prevention and child protection. WHO (2006) provides guidelines for implementing outcome evaluations of prevention programmes of child maltreatment. However, most efforts are directed at one level alone, e.g. media campaigns that target the general public, school programmes that target children (and to a lesser extent parents) and therapeutic services.

\section{Media campaigns}

Hoefnagels \& Baartman (1997) and Hoefnagels and Mudde (2000) report on a multimedia campaign in the Netherlands in 1991-1992 that resulted in increased disclosure of sexual abuse as measured by calls to a children's helpline before and after the campaign. Chalk \& King (1998) evaluated a CSA media campaign using interviews with 200 parents from eight US sites and found it effective in terms of increased knowledge and having a positive impact on how people would respond to children reporting sexual abuse. No differences in attitudes towards victims or offenders were noted. The need for raising public awareness of sexual abuse is underscored by such studies as Chen, Dunne \& Han (2007) who found significant proportions of parents who did not know that children most often are sexually abused by familiar people, that females can be the perpetrator, that boys can be sexually abused and that usually there are no obvious physical signs when sexual abuse has occurred. Rheingold and colleagues (2007), however, stress that media campaigns alone may not significantly affect primary prevention of CSA.

\section{School-based prevention programmes}

Studies of school-based CSA prevention programmes have repeatedly found improvements in the acquisition of knowledge and in some cases, evidence of safety 
skills, although as many authors note, these improvements do not necessarily reduce the occurrence of sexual abuse. Rispers, Aleman \& Goudena's (1997) meta-analysis also supported this finding, particularly in relation to pre-school children but noted that knowledge gained decreased over time.

Zwi, Woolfenden, O'Brien, Tait \& Williams (2007) conducted a Cochrane Review of 15 randomized controlled trials of school-based prevention programmes, predominantly conducted in the U.S. While Zwi et al.'s review found that the majority of studies reported significant improvements in knowledge measures and protective behaviours in simulated at-risk situations, only a few studies aimed to change actual behaviour, although these studies did find changes in demonstrating safe behaviours. Zwi et al. advocate caution in interpreting the results from their review. They were concerned about both the methodologies employed and the analysis involved in the original studies, and the lack of follow-up in terms of whether information was retained over time. Parents have expressed concern about the potential harm of such programmes, such as children knowing too much about sex (Chen et al., 2007) that may act as a potential barrier to introducing prevention programmes in schools (MacIntyre \& Carr, 1999). Surprisingly few studies appear to have addressed parents' perceptions of school-based sexual abuse prevention programmes.

None of these reviews provide evidence that school-based programmes reduce the incidence of sexual abuse or lead to easier access to services for children who have been abused. Outstanding issues highlighted by Zwi et al. requiring further exploration are the optimal age for interventions, whether knowledge gained is retained in the longer term, whether knowledge and skills learned transfer to real-life situations, and the optimal duration of such programmes. A criticism of such programmes by parents is that they inadequately address intrafamilial sexual abuse (McElvaney, 2008), and place an inappropriate burden on the child (Save the Children Norway, 2005). Teachers' attitudes to implementing such programmes are important given the significant variation in teacher comfort in dealing with sexuality issues in the classroom (Mayock, Kitching, \& Morgan, 2007).

The scientific literature is conclusive that school prevention programmes are effective in dealing with other social issues such as preventing bullying and drug use (see Durlak, 1995, cited in Finkelhor, Ormrod \& Turner, 2007). However, one key distinction between CSA and bullying or drug use is that in sexual abuse, the child is most often the victim of such behaviour, rather than the perpetrator. Behaviour change is therefore an explicit goal of prevention programmes aimed at preventing bullying and drug use and is often measured in evaluations of such programmes. The consensus in the sexual abuse literature is that while school prevention programmes have been found to be effective in increasing children's knowledge and skills, there is no evidence from outcome evaluation studies to suggest that these skills are transferred to real life situations and therefore prevent sexual abuse from occurring in the first place. Such outcome measures would be difficult to obtain. Nevertheless, epidemiological studies are reflecting a decline in rates of substantiated CSA in the U.S., Canada and the U.K. (Finkelhor, 2008) and schoolbased prevention programmes have been cited as a possible explanation for this decline (Finkelhor \& Jones, 2006; Jones, Finkelhor, \& Halter, 2006). 


\section{Prevention through therapy with abusers}

WHO (2006) note the value of therapeutic intervention with various groups as part of a multi-pronged approach to prevention of child abuse. Secondary prevention is noted as the objective of many therapeutic programmes for offenders. Cognitive-behaviour therapy has been found to be effective, particularly those approaches that include relapse prevention. Hall (1995, cited in Craig, Browne, \& Stringer, 2003) found a small but robust treatment effect in his meta-analysis. Alexander (1999, cited in Saunders, Berliner, $\&$ Hanson, 2004) reviewed 79 treatment studies and noted recidivism rates of $8.1 \%$ compared to $18.3 \%$ for other treatment approaches and $25.8 \%$ for untreated molesters.

Another area of prevention that has received attention in recent decades is that of targeting adolescent offenders to prevent these adolescents abusing in adulthood, given that a large proportion of sex offenders are adolescents (Synder, 2000; Snyder \& Sickmund, 2006, cited in Finkelhor et al., 2007). Outcome studies are promising, highlighting the potential of therapeutic intervention with adolescents as a way of preventing sexual abuse (O'Reilly, Carr, Marshall \& Beckett, 2004).

\section{Key components of an effective preventive strategy}

Save the Children Norway (2005) recommends that governments take a leading role in coordinating a child rights-based national policy framework to address CSA with enforceable agreements between governmental and nongovernmental agencies. According to this report, such a framework should include a strong monitoring and evaluation component, a multisectoral and multidisciplinary integrated response, an emphasis on children's consultation processes, a centralized data-gathering and research service, and integrated services for children, their families, and young and adult offenders which provide immediate response in child protection, multi-level care and, finally, sufficient resources allocated to such measures. Butchart and colleagues (WHO, 2004) have described strategies for preventing child maltreatment taking account of various developmental stages and levels of intervention at the individual, relationship, societal and community levels. An example of such a multi-level multi-sectoral approach to preventing child maltreatment in general (as opposed to CSA in particular) is that of the Triple P Positive Parenting Programme (Sanders, Markie-Dadds \& Turner, 2003, cited in WHO, 2006). This programme, developed in Australia, involves provision of media messages on positive parenting and information resources such as advice sheets and videos, short, targeted intervention for children with specific behavioural problems offered by primary care practitioners, an intensive training programme for parents, and services to address broader family issues such as relationship conflict, parental depression, anger and stress. A number of independent outcome evaluations have shown it to improve family management techniques, parental confidence in effective child rearing, and behavioural outcomes including behaviour and aggression in many parts of Europe, including Germany, Switzerland and UK, China, Hong Kong, New Zealand and the US.

A difficulty with the literature on broad-based child maltreatment prevention studies is discerning the impact of such programmes on the prevention of sexual abuse as those risk 
factors specific to sexual abuse may be neglected in such programmes. However, these programmes may have the potential for adaptation to specifically target the prevention of CSA. The literature is not lacking in helpful models and guidelines to inform prevention. It is unfortunately lacking in evidence for implementation of such models and in efforts to robustly evaluate those that have been implemented.

\section{Therapeutic Intervention}

Therapeutic intervention is only part of the response needed to children and families when sexual abuse has occurred. How child protection systems and legal institutions need to respond is discussed in the WHO World Violence Report (WHO, 2002) and guidelines for best practice in investigating allegations of sexual abuse are available in the U.S. (APSAC, 1999) and the U.K. (Home Office, 2002). The WHO report suggests that evidence is poor in support of therapy with children and families. This is not a fair assessment of the growing body of evidence to support the use of psychotherapy with children who have been sexually abused.

Children who have been sexually abused are a heterogeneous group, often with little in common other than their experience of sexual abuse. Significant proportions of young people do not appear to need therapeutic intervention following an experience of sexual abuse (Saywitz, Mannarino, Berliner, \& Cohen, 2000; Edmond, Auslander, Elze \& Bowland, 2006). Research on children who have been sexually abused is typically based on clinical and legal samples that are highly selective, based on therapeutic need and in the case of legal samples, those willing to pursue for the most part a lengthy and potentially distressing process (McElvaney, 2008). In addition, Goodman-Brown, Edelstein, Goodman, Jones \& Gordon (2003) found that families were less likely to agree to participate in research if the abuse experienced by the child was intrafamilial. There is some evidence to suggest that children abused by someone within the family represent a distinctly different group from those abused outside the family. Such features as an increased reluctance to disclose abuse (DiPietro, Runyan, \& Fredrickson, 1997; Hershkowitz, Horowitz, \& Lamb, 2005), and a higher likelihood of recantation (Malloy, Lyon, \& Quas, 2007), may militate against inclusion in therapy outcome studies. In addition, there is some evidence to suggest that those who have abused within the family show less improvement following therapy (Hetzel-Riggin, Brausch, \& Montgomery, 2007) and may be more subject to the cumulative impact of polyvictimization (Finkelhor, et al., 2007) due to exposure to both sexual and emotional abuse. Psychotherapy outcome studies for the most part involve samples of children who have been sexually abused, without distinguishing between those abused within the family or by someone outside the family. Therefore, the review below focuses on effectiveness of therapy with sexual abuse samples, not specifically with intrafamilial abuse samples.

\section{Psychotherapy effectiveness}

Much research on psychotherapy effectiveness with children who have been sexually abused is concerned with comparing different modalities of therapy. Evidence has been found for various therapeutic interventions in review studies ranging from cognitive- 
behavioural therapy and abuse-specific therapy (Saywitz et al., 2000; Saunders et al., 2004), art therapy (Kolko,1987), family therapy (Silovsky \& Hembree-Kigin,1994) and group therapy (Silovsky \& Hembree-Kigin, 1994), psychodrama (Avinger \& Jones, 2007). Trowell et al. (2002) provided evidence for both psychoanalytic psychotherapy and psychoeducational group therapy in a randomised controlled trial study.

Meta-analyses of group treatment outcomes for sexually abused children and adolescents found a significant effect size for group treatments (Reeker, Ensing and Elliott, 1997; Hetzel-Riggin et al., 2007), as did a meta-analysis of play therapy studies (Bratton, Ray, Rhine \& Jones, 2005).

Hetzel-Riggin et al. (2007) looked at both the effect of treatment modality and also investigated different secondary problems such as behaviour problems, and psychological distress. They concluded that therapy was more effective than no therapy with play therapy being more effective for social functioning. Cognitive-behavioural, abusespecific and supportive therapy in either group or individual formats was the most effective for behaviour problems, while cognitive-behavioural, family, and individual therapy (modality unspecified) was most effective for psychological distress. Abusespecific, cognitive-behavioural, and group therapy was found to be most effective for low self-concept. The authors conclude that the choice of therapy modality should depend on the child's main presenting secondary problem.

Outcomes in general for children who have been sexually abused are more optimistic for those who have parental support (Everson, Hunter, Runyon, Edelsohn, \& Coulter, 1989; Tricket, 1997). Chandy, Blum \& Resnick (1997) in their survey of adolescent boys found that one of the most powerful predictors of resilience was the perception that their parents cared about them. Other researchers have found support for concurrent intervention with abused children and their non-abusing parents, in groups or individual sessions, with concurrent parent-child sessions (Cohen, Deblinger, Mannarino, \& Steer, 2004; Putnam, 2003; Ramchandani \& Jones, 2003; Reeker et al., 1997). Other areas requiring further research are the role of prosocial peer relationships as a potential buffer to the effects of child abuse and neglect (Cicchetti, Toth, \& Maughan, 2000) and how understanding contextual characteristics and the mediation of social supports may affect the sequelae of child maltreatment (Pepin \& Banyard, 2006).

\section{Evidence from generic psychotherapy literature}

The known prevalence of sexual abuse among clinical populations and the underreporting of sexual abuse both underscore the relevance of the generic psychotherapy outcome literature to the field of CSA. This literature provides ample evidence of the effectiveness of psychotherapy as an intervention with children and adolescents with psychological difficulties that may arise from many sources, one of which is frequently CSA. Carr (2007) cites four broad meta-analyses of studies involving children with a broad range of psychological difficulties receiving a variety of different interventions, which included 350 treatment outcome studies. Effect sizes ranged from .71 to .79, indicating that the average child receiving therapy fared better than $76 \%$ to $81 \%$ of children in control groups (Casey \& Berman, 1985; Kazdin, Bass, Ayers, \& Rodgers, 1990; Weisz, Weiss, 
Alicke, \& Klotz, 1987; Weisz, Weiss, Han, Granger, \& Morton, 1995). Two of these studies found that effect sizes were maintained at six months' follow up (Weisz et al., 1987, Weisz et al., 1995). Carr also found a 'dose effect' relationship in psychotherapy, suggesting that $20-45$ sessions are necessary for $50-75 \%$ of psychotherapy clients to recover.

As with the literature on therapy with children who have been sexually abused, various therapeutic models have been found to be effective with clinical populations. Such findings emanate from reviews of meta-analyses on cognitive-behavioural therapy (Butler, Chapman, Forman \& Beck, 2006) reviews of both controlled studies and those without control groups on psychoanalytic psychotherapy in Germany (Richter et al., 2002; Loew et al., 2002, respectively, cited in Carr, 2007) and in the U.K. (Fonagy et al., 2002; Kennedy, 2004) and a review of meta-analyses of family therapy studies (Shadish $\&$ Baldwin, 2003, cited in Carr, 2007). These findings support the use of psychotherapy as an empirically-based intervention with children and adolescents with psychological difficulties.

The ecological approach advocated in the area of prevention has equally valid application to the therapeutic response to sexual abuse but is rarely used to inform intervention. Levendosky \& Buttenheim (2000) report on a single case study where the therapy was based on an integrated relational and trauma theory perspective through a systemic approach working directly within the family, school and social service agencies. Although examples of working with both the victim and the offender are not uncommon in clinical practice, the mutual benefits of such work to both victim and offender, particularly in cases of intrafamilial sexual abuse, have received little attention in the research literature.

Hetzel-Riggin et al. (2007) note that because of the heterogeneity of samples in their review, this logically suggests that some therapy modalities may be more effective than others depending on the presenting secondary problems. Saunders et al. (2004) note that the interventions with the most empirical support tend to be based on behavioural or cognitive behavioural theoretical approaches, utilise behavioural and cognitive intervention procedures and techniques, and intervene at both the individual child and parent/family levels. Most of the programmes reviewed are based on a cognitive behavioural approach with little reference to other modalities. The current thinking in psychotherapy is that common factors across psychotherapy modalities have a greater impact on whether clients benefit from psychotherapy than specific factors (Carr, 2007). According to Carr, the most important single common factor in psychotherapy outcome is the therapeutic relationship or working alliance, where the therapist is empathic and collaborative and the client is co-operative and committed to recovery. Carr notes that one of the challenges of examining the evidence for psychotherapy is the caution required in concluding that because cognitive behavioural therapy has been more frequently evaluated than other interventions, it is therefore more effective. Macdonald, Higgins \& Ramchandani (2006) conducted a Cochrane Review of the evidence base for cognitive behavioural interventions with children and adolescents who have been sexually abused. Their review, involving ten randomized control studies, while confirming the potential of 
CBT (particularly trauma-focussed approaches) as a means of addressing the adverse consequences of CSA, highlighted the tenuousness of the evidence base and the need for more carefully conducted and better reported trials.

\section{The child's perspective}

Recent developments in the field of sexual abuse research have emphasized the importance of involving children directly in the research process (McElvaney, 2008). Mudaly \& Goddard (2006) asked children directly about their experiences of a sexual abuse intervention service, which included both assessment and therapeutic services. Young people's views about child protection and police intervention highlights the complexity of responding to young people's needs in ways that do not render them even more helpless following experiences of abuse. The use of qualitative methodologies can help identify themes or areas of investigation of importance to children themselves.

Reviews of the literature have pointed to the methodological difficulties associated with research studies - small samples with corresponding low predictive power, lack of detail in relation to study design and content of therapeutic intervention, and lack of control group. As with the ecological approach advocated in the prevention literature, a centrally co-ordinated, well-resourced holistic approach to therapeutic outcome evaluation is needed to ensure that limited resources are allocated to meeting the needs of children and families who have been affected by CSA. Saunders et al. (2004) offer 22 general principles of treatment for children that emphasize the importance of conducting comprehensive needs-based assessments, providing evidence based interventions, including parents and caregivers in the therapeutic work, offering support to other family members where indicated, including the offender and matching the needs of clients to the intervention offered.

\section{Cultural issues \& accessing help}

Very little information is available on whether cultural differences exist in the relative efficacy of different therapeutic interventions (Cohen, Deblinger, Mannarino, \& de Arellano, 2001). Cohen et al. do suggest that certain cultural groups may have value systems that encourage them to engage with psychological services and influence expectations of therapy. Families from all cultural backgrounds may need help in accessing therapy services. In one U.S. study conducted through telephone interviews with 157 parents whose children had suffered a serious sexual or physical assault in the previous year, only $22 \%$ of these parents had even considered getting mental health treatment for their victimized children (Kopiec, Finkelhor, \& Wolak, 2004). According to Carr's (2007) extensive review, clients who are able to access therapy more quickly (and who spend little time on waiting lists) are more likely to engage in therapy. Some authors have suggested that cultural differences and associated attitudes towards purity/virginity and/or stigmatization of those sexually victimized influence whether children are more or less likely to disclose experiences of sexual abuse (Kazarian \& Kazarian, 1998;

Muntarbhorn, 1990; Toukmanian \& Brouwers, 1998). According to Saunders et al. (2004), the role of cultural, racial, ethnic, and religious identification on treatment 
response in cases of child abuse is an important area for future research, and needs to be considered in all treatment planning decisions.

\section{Conclusion}

Notwithstanding significant methodological limitations, the extant literature reveals a growing body of well-designed studies from across the globe indicating the need to view CSA as an international public health problem. The Stockholm (1996) and Yokohama (2001) World Congress against Commercial Sexual Exploitation of Children (CSEC) focussed on commercial forms of child sexual exploitation, such as sex-tourism, prostitution, pornography and trafficking. There is a recognition that the much more pervasive sexual abuse of children in their own families and communities, by perpetrators trusted and known to them, needs to be addressed as part of the global initiative to tackle CSA. For example, a 1996 Eastern and Southern African Regional Consultation on CSEC observed that, apart from commercial sexual abuse of children,

there were more alarming occurrences of the non-commercial sexual abuse of children in the form of domestic violence and incest ... far more attention needs to be paid to abuse in the home as both a primary cause of commercial sexual exploitation and as a far more serious problem in itself (Unicef \& ANNPCAN, 2001, p. 8).

The identity of perpetrators is of considerable importance. Victims are far less likely to report CSA when it is perpetrated by somebody close to them for reasons of fear of perpetrator, fear of consequences, embarrassment, shame (see Pipe, Lamb, Orbach \& Cederborg, 2007 for a review on inhibitors to disclosure). This increases the likelihood of environmental systems, such as police, hospitals and courts becoming aware of abuse by strangers to a disproportionate degree.

Evidence that the sexual abuse of children is universally widespread, and is most frequently perpetrated by family members, neighbours, peers and others known to the child or adolescent is indisputable. CDCP \& Unicef (2007) provide a strong argument for the need to have good data about CSA:

In the absence of good prevalence estimates the tendency in many countries is to believe that childhood sexual violence is not a problem. Further, progress towards prevention cannot be monitored without reliable population based baseline and follow-up data. Population based data can also be used to identify potential risk and protective factors for sexual violence in order to develop effective prevention strategies (p. 11).

The short and long term effects of CSA are variable, depending on the age of onset, number and identity of perpetrators, severity, degree of family support and other factors. In addition to socio-emotional and mental health sequelae, studies have consistently found that victims are vulnerable to subsequent sexual revictimization in adolescence and adulthood. Russell's 1986 study suggested that the risk is twofold for women who experienced intrafamilial sexual abuse before the age of 14 for rape or attempted rape 
after the age of 14, while Roodman and Clum's (2001) review of 19 empirical studies found an effect size of .59 when including broader definitions of CSA.

Studies have also found a link between CSA and later engagement in high-risk sexual behaviour, prostitution and sexual promiscuity. Individuals who have experienced CSA are also more likely than nonvictims to engage in potentially harmful and damaging highrisk sexual behaviours, such as early age at first intercourse, multiple partners, unprotected sex resulting in unplanned pregnancies or sexually transmitted diseases and prostitution. While this relationship cannot be considered to be a causal relationship, there is an abundance of evidence that the experience of childhood sexual abuse, in particular penetrative abuse, significantly increases the risk for such high-risk sexual behaviours. More severe forms of sexual abuse and the co-existence of physical abuse, increases the risks for later revictimization and engagement in high risk sexual behaviours.

Mediating factors such as parental psychopathology, family conflict versus a supportive family environment, and leaving home at an early age appear to play a role in these relationships. However, there is a need for research that separates out the confounding influence of such variables in order to realise the true influence of such mediators.

Cross-sectional studies cannot explain these outcomes. While theoretical explanatory models that focus on the psycho-social impacts of the abuse on the individual have been commonly relied on to enhance our understanding of these links, these models neglect contextual factors which according to some authors are equally important in considering such relationships. Ecological models, such as that proposed by Grauerholz (2000), that incorporate explanations at the individual, family, community and societal level, are promising. Grauerholz emphasises the reciprocal nature of influences whereby individual factors such as psychological coping strategies interact with environmental factors such as exposure to family environments and high risk situations leads to the greater risk of revictimization and engagement in high risk sexual behaviours. Grauerholz' theory is consistent with a changing focus in the literature from the individual to interpersonal and cultural factors within society.

Interventions in the area of prevention of CSA have not kept apace with international policy guidelines. Thus, whether such guidelines have empirical support is open to question. Nevertheless, preliminary attempts at mass media campaigns and school-based prevention programmes have shown some improvements in the increase of knowledge and to a more limited degree, the acquisition of skills. As yet, there is no evidence that interventions have prevented sexual abuse from occurring in the first place.

However, broad-based prevention programmes aimed at preventing child maltreatment in general (as opposed to CSA in particular) may have something to offer in informing CSA prevention programmes. Centralised responsibility for coordinating such a broad-based approach appears to be crucial to its success. While an ecological approach is promoted in the area of prevention, the current literature review highlights the need for such an approach in the area of therapy - with the child who has been abused, the family (which may or may not include the abuser) and the community. To date, such an approach has not been evident in practice or in the research literature. There is considerable evidence to 
support the use of various therapeutic modalities in intervening with children and families following the experience of CSA. However, researchers have identified significant methodological limitations in the extant research literature that impede the making of recommendations for implementing existing therapeutic programmes unreservedly.

We conclude by quoting CDCP \& Unicef (2007), who state "[sexual] violence against children is both a public health problem and a human rights problem" (p. 28). The former because of the negative sequelae experienced in the population of victims (far too high a population in many societies), and the latter because of the infringement of the personal integrity of the victim.

\section{References}

American Professional Society on the Abuse of Children (APSAC) (1999). Guidelines for psychosocial evaluation of suspected sexual abuse in young children Chicago, IL: APSAC.

Arata, C.M. (2000). From child to adult victim: A model for predicting sexual revictimization. Child Maltreatment, 5, 1, 28-38

Arata, C.M. (2002). Child sexual abuse and sexual revictimization. Clinical Psychology: Science and Practice, 9, 2, 135-164

Avinger, K. A., \& Jones, D. H. (2007). Group treatment of sexually abused adolescent girls: A review of outcome studies. American Journal of Family Therapy, 35(4), 315-326.

Bagley, C. and Young, L. (1987). Juvenile prostitution and child sexual abuse: A controlled study. Canadian Journal of Community Mental Health, 6, 5-26

Belsky, J. (1980). Child maltreatment: An ecological integration. American Psychologist, 35, 320-335.

Bratton, S. C., Ray, D., Rhine, T., \& Jones, L. (2005). The efficacy of play therapy with children: A meta-analytic review of treatment outcomes. Professional Psychology: Research and Practice, 36, 376-390.

Briere, J. (1992). Methodological issues in the study of sexual abuse effects. Journal of Consulting and Clinical Psychology, 60, 196-203.

Briere, J. (1997). Psychological assessment of adult posttraumatic states. Washington, DC: American Psychological Association.

Briere, J. \& Elliott, D. (2003). Prevalence and psychological sequelae of self-reported childhood physical and sexual abuse in a general population sample of men and women. Child Abuse and Neglect, 27, 1205-1222.

Bronfenbrenner, U. (1979). The ecology of human development. Cambridge, MA: Harvard University Press.

Browne, K. D., Hanks, H., Stratton, P., \& Hamilton-Giachritsis, C. (Eds.). (2002). Early prediction and prevention of child abuse: A handbook. Chichester: J. Wiley.

Butler, A., Chapman, J., Forman, E., \& Beck, A. (2006). The empirical status of cognitive-behavioural therapy: A review of meta-analyses. Clinical Psychology Review, 26, 1, 17-31

Carr, A. (2007). The effectiveness of psychotherapy: A review of research. Dublin: Irish Council of Psychotherapy. 
Casey, R. J., \& Berman, J. S. (1985). The outcome of psychotherapy with children. Psychological Bulletin, 98, 388-400.

Chalk, R., \& King, P. (1998). Assessing family violence interventions. American Journal of Preventive Medicine, 14, 4, 289-292.

Chandy, J. M., Blum, R. W., \& Resnick, M. D. (1997). Sexually abused male adolescents: How vulnerable are they? Journal of Child Sexual Abuse, 6(2), 1-16.

CDCP \& Unicef (2007). Violence Against Children in Swaziland: Findings from a National Survey on Violence Against Children in Swaziland. CDCP \& Unicef.

Chen, J.Q., Dunne, M. \& Han, P. (2004). Child sexual abuse in China: A study of adolescents in four provinces. Child Abuse \& Neglect, 28, 11, 1171-1186.

Chen, J. Q., Dunne, M., \& Han, P. (2007). Prevention of child sexual abuse in China: Knowledge, attitudes, and communication practices of parents of elementary school children. Child Abuse \& Neglect, 31, 747-755.

Cicchetti, D., Toth, S. \& Maughan, A. (2006). An ecological-transactional model of child maltreatment. In A. Samaroff, M. Lewis, S. Miller, (Eds.) Handbook of Developmental Psychopathology ( $2^{\text {nd }}$ ed.), Dordrecht, Netherlands: Kluwer Academic Publishers.

Classen, C., Palesh, O. \& Aggarwal, R. (2005). Sexual revictimization: A review of the literature. Trauma, Violence and Abuse, 6, 2, 103-129.

Cohen, J. A., Deblinger, E., Mannarino, A. P., \& de Arellano, M. A. (2001). The importance of culture in treating abused and neglected children: An empirical review. Child Maltreatment, 6, 2, 148-157.

Cohen, J. A., Deblinger, E., Mannarino, A. P., \& Steer, R. A. (2004). A multisite, randomized controlled trial for children with sexual abuse-related PTSD symptoms. Journal of the American Academy of Child and Adolescent Psychiatry, 43, 4, 393-402.

Collings, S.J. (1991). Childhood sexual abuse in a sample of South African university males: Prevalence and risk factors. South African Journal of Psychology, 21, 3, 153-158.

Collings, S.J. (1997). Child sexual abuse in a sample of South African women students: prevalence, characteristics, and long-term effects. South African Journal of Psychology, 27(1), 37-42.

Collishaw, S., Pickles, A., Messer, J., Rutter, M., Shearer, C. \& Maughan, B. (2007). Resilience to adult psychopathology following childhood maltreatment: Evidence from a community sample. Child Abuse \& Neglect, 31(3), 211-229.

Craig, L. A., Browne, K. D., \& Stringer, I. T. (2003). Treatment and sexual offense recidivism. Trauma, Violence, \& Abuse, 4(1), 70-89.

DeMause, L. (1991). The universality of incest. The Journal of Psychohistory, 19(2), 123-164.

DiPietro, E. K., Runyan, D. K., \& Fredrickson, D. D. (1997). Predictors of disclosure during medical evaluation for suspected sexual abuse. Journal of Child Sexual Abuse, 1(6), 133-142.

Dube, S., Anda, R., Whitfield, C., Brown, D., Felitti, V., Dong, M. \& Giles, W. (2005). Long term consequences of childhood sexual abuse by gender of victim. American Journal of Preventative Medicine, 28(5), 430-438. 
Dunkle, K., Jewkes, R., Brown, H., Yoshihama, M., Gray, G., McIntyre, J. and Harlow, S. (2004). Prevalence and patterns of gender based violence and revictimization among woman attending antenatal clinics in Soweto, South Africa. American Journal of Epidemiology, 160, 3, 230-239.

Edmond, T., Auslander, W., Ezle, D., \& Bowland, S. (2006). Signs of resilience in sexually abused adolescent girls in the foster care system. Journal of Child Sexual Abuse, 15(1), 1-28.

Elbedour, S., Abu-Bader, S., Onwuegbuzie, A., Abu-Rabia, A. \& El-Aassam, S. (2006). The scope of sexual, physical, and psychological abuse in a Bedouin-Arab community of female adolescents: The interplay of racism, urbanization, polygamy, family honor, and the social marginalization of women. Child Abuse \& Neglect 30, 3, 215-229.

Everson, M. D., Hunter, W. M., Runyon, D. K., Edelsohn, G. A., \& Coulter, M. L. (1989). Maternal support following disclosure of incest. American Journal of Orthopsychiatry, 59. 197-207

Fanslow, J. L., Robinson, E., Crengle, S. \& Perese, L. (2007). Prevalence of child sexual abuse reported by a cross-sectional sample of New Zealand women. Child Abuse \& Neglect 31, 9, 935-945.

Fergusson, D., Horwood, J. and Lynskey, M. (1997). Childhood sexual abuse, adolescent sexual behaviours and sexual revictimization. Child Abuse and Neglect, 21, 8, 789-803.

Finkelhor, D. (1990). Early and long term effects of child sexual abuse: An update. Professional Psychology: Research and Practice, 21, 325-330.

Finkelhor, D. (1994). The international epidemiology of child sexual abuse. Child Abuse \& Neglect, 18, 5, 409-417.

Finkelhor, D. (2008). Lessons from the decline in sexual abuse. Paper presented at the St. Clare's Unit \& St. Louise's Unit Joint Annual Conference, Dublin.

Finkelhor, D. \& Browne, A. (1985). The traumatic impact of child sexual abuse. American Journal of Orthopsychiatry, 55, 530-541.

Finkelhor, D., \& Jones, L. (2006). Why have child maltreatment and child victimization declined? Journal of Social Issues, 62, 685-716.

Finkelhor, D., Ormrod, R. K., \& Turner, H. A. (2007). Poly-victimization: A neglected component in child victimization. Child Abuse \& Neglect, 31, 7-26.

Fleming, J., Mullen, P., Sibthorpe, B., Bammer, G. (1999). The long term impact of childhood sexual abuse in Australian women. Child Abuse \& Neglect, 23, 145159.

Flowers, R. (1998). The prostitution of women and girls. Jefferson, NC: McFarland.

Fonagy, P., Clarkin, J., Gerber, A., Kachele, H., Krause, R., \& Jones, E. E. (2002). Open door review of outcome studies in psychoanalysis. London: International Psychoanalytic Association.

García-Moreno, C. \& Watts, C. (2000). Violence against women: Its importance for HIV/AIDS. Aids, 14 suppl 3, 253-265.

García-Moreno, C., Jansen, H., Ellsberg, M., Heise, L. \& Watts, C. (2005). WHO Multicountry study on women's health and domestic violence against women. Geneva: World Health Organisation. 
Goodman-Brown, T.B., Edelstein, R.S., Goodman, G.S., Jones D.P.H. \& Gordon, D.S. (2003). Why children tell: A model of children's disclosure of sexual abuse. Child Abuse \& Neglect, 27, 525-540.

Grauerholz, L. (2000). An ecological approach to understanding sexual revictimization: Linking personal, interpersonal, and sociocultural factors and processes. Child Maltreatment, 5, 5-17.

Hershkowitz, I., Horowitz, D., \& Lamb, M. E. (2005). Trends in children's disclosure of abuse in Israel: A national study. Child Abuse \& Neglect, 29(11), 1203-1214.

Hetzel-Riggin, M. D., Brausch, A. M., \& Montgomery, B. S. (2007). A meta-analytic investigation of therapy modality outcomes for sexually abused children and adolescents: An exploratory study. Child Abuse \& Neglect, 31, 125-141.

Hoefnagels, C., \& Baartman, H. (1997). On the threshold of disclosure: The effects of a mass media field experiment. Child Abuse \& Neglect, 21, 557-573.

Hoefnagels, C., \& Mudde, A. (2000). Mass media and disclosures of child abuse in the perspective of secondary prevention: Putting ideas into practice Child Abuse \& Neglect, 24, 1091-1101.

Home Office (2002). Achieving best evidence in criminal proceedings: Guidance for vulnerable or intimidated witnesses, including children. London: Her Majesty's Stationery Office.

Humphrey, J.A. \& White, J.W. (2000). Women's vulnerability to sexual assault from adolescence to young adulthood. Journal of Adolescent Health, 27, 419-424.

Jewkes, R., Levin, L., Mbananga, N. \& Bradshaw, D. (2002). Rape of girls in South Africa. The Lancet, 359, 26, 319-320.

Jones, L., Finkelhor, D., \& Halter, S. (2006). Child maltreatment trends in the 1990's: Why does neglect differ from sexual and physical abuse. Child Maltreatment, 11, 107-120.

Kazarian, S. S., \& Kazarian, L. Z. (1998). Cultural aspects of family violence In S. S. Kazarian \& D. R. Evan (Eds.), Cultural clinical psychology: Theory, research and practice (pp. 316-347). Oxford: Oxford Press.

Kazdin, A., Bass, D., Ayers, W. A., \& Rodgers, A. (1990). Empirical and clinical focus of child and adolescent psychotherapy research. Journal of Consulting \& Clinical Psychology, 58, 729-740.

Kempe, C., Silverman, F., Steele, B., Droegmueller, W. \& Silver, H. (1962). The battered child syndrome. Journal of the American Medical Association, 181, $17-$ 24.

Kendall-Tackett, Williams \& Finkelhor (1993). Impact of sexual abuse on children: A review and synthesis of the literature. Psychological Bulletin, 113, 164-180

Kennedy, E. (2004). Child and adolescent psychotherapy: A systematic review of psychoanalytic approaches. London: North Central London, NHS Strategic Health Authority.

King, G., Guilbert, P., Ward, D., Arwidson, P. \& Noubary, F. (2006). Correlates of sexual abuse and smoking among French adults. Child Abuse \& Neglect 30(6), 709-723.

Klein, H., Elifson, K. and Sterk, C. 2007. Childhood neglect and adulthood involvement in HIV-related risk behavior. Child Abuse \& Neglect, 31, 39-53. 
Kolko, D. J. (1987). Treatment of child sexual abuse: Programs, progress, and prospects. Journal of Family Violence, 2, 303-318.

Kolko, D. J., Cohen, J. A., Mannarino, A. P., Baumann, B. L., \& Knudsen, K. (2008). Community treatment of child sexual abuse: A survey of practitioners in the National Child Traumatic Stress Network. Adm Policy Mental Health.

Kopiec, K., Finkelhor, D., \& Wolak, J. (2004). Which juvenile crime victims get mental health treatment? Child Abuse \& Neglect, 28, 45-59.

Korbin, J.E. (Ed.) (1981). Child abuse and neglect: Cross cultural perspectives. Berkeley: University of California Press.

Lachman, P. (1996). Child protection in Africa: The road ahead. Child Abuse \& Neglect, 20, 7, 543-547.

Lalor, K. (2008). Child sexual abuse and HIV transmission in sub-Saharan Africa. Child Abuse Review, 17, 94-107.

Levendosky, A. A., \& Buttenheim, M. (2000). A multi-method treatment for child survivors of sexual abuse: An intervention informed by relational and trauma theories. Journal of Child Sexual Abuse, 9, 2, 1-19.

Macdonald, G. M., Higgins, J. P. T., \& Ramchandani, P. (2006). Cognitive-behavioural interventions for children who have been sexually abused. Cochrane Database of Systematic Reviews (Issue 4 Art. No.: CD001930. DOI: 10.1002/14651858.CD001930.pub2.).

MacIntyre, D., \& Carr, A. (1999). Evaluation of the effectiveness of the Stay Safe primary prevention programme for child sexual abuse. Child Abuse \& Neglect, 23, 1307-1325.

Mandoki, C. \& Burkhart, B. (1989). Sexual victimization: Is there a vicious cycle? Violence and Victims, 4, 3, 179-190.

Masson, J. (1992, $3^{\text {rd }}$ edition). The assault on truth: Freud and child sexual abuse. London: Fontana

Malloy, L. C., Lyon, T. D., \& Quas, J. (2007). Filial dependency and recantation of child sexual abuse allegations. Journal of the American Academy of Child and Adolescent Psychiatry, 46, 2, 162-170.

May-Chahal, C. \& Cawson, P. (2005). Measuring child maltreatment in the United Kingdom: A study of the prevalence of child abuse and neglect. Child Abuse \& Neglect, 29, 9, 969-984.

Mayall, A. \& Gold, S. (1995). Definitional issues and mediating variables in the sexual revictimization of women sexually abused as children. Journal of Interpersonal Violence, 10, 1, 26-42.

Mayock, P., Kitching, K., \& Morgan, M. (2007). RSE in the context of SPHE: An assessment of the challenges to full implementation of the programme in postprimary schools. Dublin: Crisis Pregnancy Agency/Dept of Education and Science.

McCrann, D., Lalor, K. \& Katabaro, K. (2006). Childhood sexual abuse among university students in Tanzania. Child Abuse \& Neglect, 30, 1343-1351.

McGee, H., Garavan, R., de Barra, M., Byrne, J., \& Conroy, R. (2002). The SAVI Report: Sexual abuse and violence in Ireland - a national study of Irish experiences, beliefs and attitudes concerning sexual violence. Dublin: The Liffey Press \& Dublin Rape Crisis Centre. 
McElvaney, R. (2008). How children tell: Containing the secret of child sexual abuse: Trinity College Dublin: Unpublished PhD Dissertation.

Messman-Moore, T., \& Long, P. (2003). The role of childhood sexual abuse sequelae in the sexual revictimization of women: An empirical review and theoretical reformulation. Clinical Psychology Review, 23, 537-571.

Mudaly, N., \& Goddard, C. (2006). The truth is longer than a lie: Children's experiences of abuse and professional interventions. London: Jessica Kingsley Publishers.

Muntarbhorn. (1990). Sexual exploitation of children. New York: United National Publications.

Newcomb, M. Locke, T and Goodyear, R. (2003). Childhood experiences and psychosocial influences on HIV risk among adolescent Latinas in Southern California. Cultural Diversity and Ethnic Minority Psychology, 9(3), 219-235.

Noll, J., Trickett, P. \& Putnam, F. (2003). A prospective investigation of the impact of childhood sexual abuse on the development of sexuality. Journal of Consulting and Clinical Psychology, 71(3), 575-586.

Nyamathi, A., Flaskerud, J. \& Leake, B. (1997). HIV-risk behaviors and mental health characteristics among homeless or drug-recovering women and their closest sources of social support. Nursing Research, 46, 133-137.

O’Reilly, G., Carr, A., Marshall, W.L. \& Beckett, R.C. (2004). Handbook of clinical interventions with juvenile sex offenders. London: Taylor and Francis Ltd.

Paine, M.L. \& Hansen, D.J. (2002). Factors influencing children to self-disclose sexual abuse. Clinical Psychology Review, 22, 271-295.

Pepin, E.N. \& Banyard, V.L. (2006). Social support: A mediator between child maltreatment and developmental outcomes. Journal of Youth and Adolescence, 35, 4, pp.617-630.

Pereda,N., Guilera, G., Forns, M. \& Gomez-Benito, J. (2009). The international epidemiology of child sexual abuse: A continuation of Finkelhor (1994). Child Abuse and Neglect, 33, 331-342.

Pipe, M. E., Lamb, M., Orbach, Y., \& Cederborg, A. C. (Eds.). (2007). Child sexual abuse: Disclosure, delay and denial. New Jersey: Lawrence Erhbaum Association.

Polusny, M. \& Follette, V. (1995). Long-term correlates of child sexual abuse: Theory and review of the empirical literature. Applied and Preventative Psychology, 4, 143-166.

Potter, K., Martin, J., Romans, S. (1999). Early developmental experiences of female sex workers: A comparative analysis. Australian and New Zealand Journal of Psychiatry, 33(6), 935-940.

Putnam, F. (2003). Ten-year research update review: Child sexual abuse. Journal of the American Academy of Child and Adolescent Psychiatry, 42, 269-278.

Ramchandani, P. \& Jones, D.P.H. (2003). Treating psychological symptoms in sexually abused children: From research findings to service provision, British Journal of Psychiatry, 183(6), 484-490

Reeker, J., Ensing, D., \& Elliott, R. (1997). A meta-analytic investigation of group treatment outcomes for sexually abused children. Child Abuse \& Neglect, 21, 669680.

Rheingold, A. A., Campbell, C., Self-Brown, S., de Arellano, M. A., Resnick, H., \& Kilpatrick, D. (2007). Prevention of child sexual abuse: Evaluation of a community media campaign. Child Maltreatment, 12(4), 352-363. 
Rispers, J., Aleman, A., \& Goudena, P. P. (1997). Prevention of child sexual abuse victimization: A meta-analysis of school programs Child Abuse \& Neglect, 21, 975-987.

Runyan, D. (2000). The ethical, legal and methodological implications of directly asking children about abuse. Journal of Interpersonal Violence, 15, 675-681.

Roodman, A. and Clum, G. (2001). Revictimization rates and method variance: A metaanalysis. Clinical Psychology Review, 21 (2), 183-204.

Rushton, A., \& Miles, G. (2000). A study of a support service for the current carers of sexually abused girls. Clinical Psychology and Psychiatry, 5, 3, 411-416.

Russell, D. (1986). The secret trauma: Incest in the lives of girls and women. New York: Basic Books.

Sandberg, D., Matorin, A. \& Lynn, S. (1999). Dissociation, posttraumatic symptomatology, and sexual revictimization: A prospective examination of mediator and moderator effects. Journal of Traumatic Stress, 12, 1, 127-138.

Sanders, B. and Moore, D. (1999). Childhood maltreatment and date rape. Journal of Interpersonal Violence, 14, 2, 115-124.

Saunders, B. E., Berliner, L., \& Hanson, R. F. (2004). Child physical and sexual abuse: Guidelines for treatment

Save the Children Norway (2005). 10 essential learning points: Listen and speak out against sexual abuse of girls and boys. Global submission by The International Save the Children Alliance, UN study on violence against children.

Saywitz, K. J., Mannarino, A. P., Berliner, L., \& Cohen, J. A. (2000). Treatment for sexually abused children and adolescents. American Psychologist, 55, 1040-1049.

Schultz, L.G. (1982). Child sexual abuse in historical perspective. Journal of Social Work and Human Sexuality, 1, 21-35.

Silberschmidt, M. (2001). Disempowerment of men in rural and urban East Africa: implications for male identity and sexual behavior. World Development, 294, 657671.

Silbert, M., and Pines, A. (1982). Victimization of Street Prostitutes. Victimology, 7, 122133.

Silovsky, J. F., \& Hembree-Kigin, T. L. (1994). Family and group treatment for sexually abused children: A review. Journal of Child Sexual Abuse, 3, 1-20.

Slonim-Nevo, V. and Mukuka, L. (2007). Child abuse and AIDS-related knowledge, attitudes and behaviour among adolescents in Zambia. Child Abuse \& Neglect, 31, 143-159.

Steel, J. \& Herlitz, C. (2005). The association between childhood and adolescent sexual abuse and proxies for sexual risk behavior: A random sample of the general population of Sweden. Child Abuse \& Neglect, 29, 10, 1141-1153.

Stoltz, J.-A. M., Shannon, K., Kerr, T., Zhang, R., Montaner, J. \& Wood, E. (2007). Associations between childhood maltreatment and sex work in a cohort of drugusing youth. Social Science \& Medicine 65, 6, 1214-1221.

Toukmanian, S.G. \& Brouwers, M.C. (1998). Cultural aspects of self-disclosure and psychotherapy. In S.S. Kazarian \& D.R. Evans (Eds.), Cultural clinical psychology: Theory, research and practice (pp. 106-126). New York: Oxford University Press. 
Tricket, P. K. (1997). Sexual and physical abuse and the development of social competence. In S. S. Luthar, J. A. Burack, D. Cicchetti \& J. R. Weisz (Eds.), Developmental psychopathology: Perspectives on adjustment, risk and danger New York: Cambridge University Press.

Trowell, J., Kolvin, I., Weermanthri, T., Sadowski, H., Berelowitz, M., Glaser, D., et al. (2002). Psychotherapy for sexually abused girls: Psychopathological outcome findings and patterns of change. British Journal of Psychiatry, 180, 234-247.

United Nations (UN). (2008). Report submitted by the Special Rapporteur on the sale of children, child prostitution and child pornography, Juan Miguel Petit. $\mathrm{A} / \mathrm{HRC} / 7 / 8$

Unicef \& ANNPCAN. (2001). Analysis of the situation of sexual exploitation of children in the Eastern and Southern Africa region. www.focalpointngo.org/yokohama/latestnews/CSECEastSouthernAfricaDraft.

Weisz, J. R., Weiss, B., Alicke, M. D., \& Klotz, M. L. (1987). Effectiveness of psychotherapy with children and adolescents: A meta-analysis for clinicians. Journal of Consulting \& Clinical Psychology, 55, 542-549.

Weisz, J. R., Weiss, B., Han, S. S., Granger, D. A., \& Morton, T. (1995). Effects of psychotherapy with children and adolescents revisited: A meta-analysis of treatment outcome studies. Psychological Bulletin, 117, 450-468.

WHO (2002). World report on violence and health. Geneva: World Health Organization.

WHO (2004). Preventing violence: A guide to implementing the recommendations of the World report on violence and health. Geneva: World Health Organization.

WHO (2006). Preventing child maltreatment: A guide to taking action and generating evidence. Geneva: World Health Organization.

WHO (2007). Preventing child maltreatment in Europe: A public health approach. Geneva: World Health Organization.

Widom, C. (1988). Sampling biases and implications for child abuse research. American Journal of Orthopsychiatry, 58, 260-270.

Widom, C.S., Czaja, S. and Dutton, M.A. (2008). Childhood victimization and lifetime revictimization. Child Abuse and Neglect, 32, 785-796.

Widom, C. \& Kuhns, J. (1996). Childhood victimization and subsequent risk for promiscuity, prostitution and teenage pregnancy: A prospective study. American Journal of Public Health, 86, 1607-1612.

Wingood, G. \& DiClemente, R. 1997. Child sexual abuse, HIV sexual risk, and gender relations of African-American women. American Journal of Preventative Medicine, 135, 380-384.

Worku, D., Gebremariam, A., Jayalakshmi, S. (2006). Child sexual abuse and its outcomes among high school students in southwest Ethiopia. Tropical Doctor 36, 137-140.

Zierler, S., Feingold, L., Laufer, D., Velentgas, P. Kantrowitz-Gordon, I. and Maye, K. (1991). Adult survivors of childhood sexual abuse and subsequent risk of HIV infection. American Journal of Public Health, 81, 5, 572-575.

Zwi, K. J., Woolfenden, S. R., Wheeler, D. M., O'Brien, T. A., Tait, P., \& Williams, K. W. (2007). School-based education programmes for the prevention of child sexual abuse (Review). In Cochrane Database of Systematic Reviews: John Wiley \& Sons. 
Acknowledgements

This paper is based on a review commissioned by ISPCAN for the Pre ' 3 rd World Congress on Sexual Exploitation' Workshop (Hong Kong, September 2008), funded by Unicef. Resources can be found at: www.ispcan.org/congress2008/wcse.html

We are grateful for the useful comments from reviewers and to Dublin Institute of Technology for its support. 